\title{
Critical Discourse Analysis of Two Letters of Complaint and Manipulation of People in Power
}

\author{
Masoumeh Karimi
}

Department of Foreign Languages, Isfahan (khorasgan) Branch, Islamic Azad University, Isfahan, Iran Email: aftowsun@yahoo.com

Hossein Heidari Tabrizi

Department of Foreign Languages, Isfahan (Khorasgan) Branch, Islamic Azad University, Isfahan, Iran Corresponding Author Email: heidaritabrizi@gmail.com

\section{Doi:10.5901/mjss.2015.v6n4s2p486}

\section{Abstract}

Critical discourse analysis is a purposeful kind of study pointing social issues and aiming at causing changes according to one's ideology and beliefs. This case study adopted a critical discourse analysis approach to investigate how typical discursive strategies introduced in Van Dijk's frame work can be helpful in presenting a positive image of ourselves and negative image of the others and result in manipulating the people in power or in establishing an ideology in society. To this end two letters of complaint were analyzed to explore whether employment of discursive characteristics could result in expressing one's views. The results of this study revealed that the letter which possessed a rich repertoire of discursive mechanisms gave the writer a better chance to define the honorable position of a teacher in society.

Keywords: Critical Discourse Analysis, Discursive Strategies, Positive Self-Presentation, Negative Other Presentation.

\section{Introduction}

The provoked awareness in theorists (Bernstein, Bourdieu, Gramsci, Foucault, Godden's and Haber mass) triggered the raising of CDA. These theorists reckon that the study of language can go far beyond the study of text in isolation, that language possesses a great power through which one is able not only to communicate what he means but also perform other social practices, have impact on audiences and achieve his or her goals. (Fairclough, 1989; Fairclough \& Wodak, 1997; Wodak, 2001a). Within the remit of CDA, linguists analyze social problems, power relationships, injustices, discrimination, bias, etc. which is manifested in a discourse. CDA purposefully seeks for a change in society. (Farclough, 1992a,b; Penny Cook, 1994; Vandijk, 1993). This change can occur at both micro and macro levels (Vandijk's 2004). Among all those who know themselves as speakers of language some will be the victims unless they raise their awareness of what language is capable to do with them (Vandijk, 1993; Wodak 1999) and how power can be exercised through language (Faiclough, 1992b).Most research reviews show that analysts main concern has mostly been focused on the strategies employed by politicians and powerful sources in their public speech where they try to actualize their ultimate goal which is to make the audience believe in what they are asserting (Biria \& Mohammadi, 2012; Duranti, 2006; Kratzer \& Benoit, 2010; Letetia Van der Poll, 2011; Piotr Cap, 2014; O'Halloran, 2004; Rashidi \& Souzandehfar, 2010). However, few studies have shown that all these strategies can also be manifested in everyday discourse between common people's textual interactions. An everyday mundane text can be as ideologically saturated as a text like presidential political inaugural speeches (Kress 1993).

Therefore, this study aims at investigating the relationship between the employment of discursive strategies and success in expressing one's view and influencing the people in power.

\section{Literature Review}

\subsection{Definition and Origin}

Critical Discourse Analysis (CDA) originated from linguistics in 1970s. Fowler is known as the father of this movement but 
later scholars such as Norman Farclough, Gunther Kress, Teun Van Dijk, Theo Van Leeuwen and Ruth Wodak initiated the formal study of CDA (Flowerdew 2013). These people contributed articles in 1993 entitled Critical Discourse Analysis. These studies show the way social power abuse, dominance and inequality are enacted, reproduced and resisted by text and talk in the social and political context (Van Dijk, 1993).One may wonder how this kind of abuse may be manifested in the discourse if both parties speak the same language; and here is when the significance of CDA is portrayed. According to Fairclough (1992b) the exercising of power and dominance happens through naturalization or as VanDijk (1993) puts it through generation of context. This potential for one group influencing the other group may be at a subconscious level where dominated group end up acting in the interest of powerful group. So Van Dijk (1998a) defines CDA as a field that is concerned with studying and analyzing written and spoken texts to reveal the discursive sources of power, dominance, inequality and bias. The result of this analysis is supposed to bring about change and awareness (Fairclough, 1992b). In this respect Fairclough (1995) introduced three dimensions in CDA: text, interaction, and social context. By this notion the analyst deals with the text at micro level and what goes on in social context at macro level (Thompson, 2002b).

\subsection{Major proponents and Their Contributions}

Fowler (1979) as the leader of CDA referred to the relationship which exists between texts and historical conditions. He is also concerned with the use of certain grammatical structures with the purpose of concealing certain agents or social actors. He names this strategy as "mystification".

Later on Hodge and Kress (1993) bring about some transformations such as transitivity, nominalization, negative incorporation and agentless passive to show how one can mystify some points. They also believe in word classes and by applying the terms such as "euphemism" and "derogation" state the strategies of manipulating reality and presenting ideologies.

In accordance with Hodge and Kress's classification Van Dijk (1997) provided some categorizations but structural kinds and maintained that it is the analyst's job to show how different kinds of structures are used for expressing various ideas. He also resorts to social analysis, cognitive analysis, and discourse analysis of the text to reveal the ideology behind words. In fact one of the greatest contributions to CDA has been the work of Van Dijk on sociocognitive model which was fallowed by his work with Walter Kintch (VanDijk, 1997). In his socio cognitive model which mainly focuses on media discourse, he intends to bridge the gap between society and discourse, working on how societal structures are related to discourse structures (Bell \& Garret 1998). To Van Dijk discourse analysis is ideology analysis and there are three components forming the triangle of "social function", "cognitive structure", and "discourse analysis". So social structures and discursive structures are related through the medium of people's cognition. In this sense he takes ideology as the attitude of a group of people about certain issues, cognition of group members. He calls this mental representation "models" which control how people act, speak, write, or understand the social practices of others. Van Dijk's (2004) framework consists of two main discursive strategies "positive self representation" (semantic macro - strategy of in group favoritism) and "negative other representation" (semantic macro - strategy of derogation of out-group). These terms are the development of what he referred to as "US" "THEM" in his earlier works (1988, 1991, 1995, 1996, 1998a, 1988b). In his framework he has provided some categories which he believes are helpful to analyze how various ideologies are expressed in various kinds of structures .A selection of his categories are as fallows:

Actor description: The way we describe actors or members of a particular society represents our ideology in a way that those who are with US will be referred to in a positive way and those we oppose are the ones we try to present negatively.

\footnotetext{
Authority: Mentioning authorities to support one's claims.

Categorization: People belong to different categories depending on their social class, race, gender, ethnicity etc.

Comparison: To portray a positive image of those who belong to another group like different races, etc.

Consensus: creating agreement and solidarity.

Disclaimer: The use of adverbial clauses of concession to express how something could have been.

Evidentiality: Mentioning of authorities, showing pictures, etc. to confirm a claim or point of view.

Hyperbole: Hyperboles are semantic rhetorical devices to make an exaggerated image of an event, or features of a person (negative or positive) to gain certain objectives.

Implication: The main idea is not mentioned directly but can be deduced or implies through familiarity with pragmatics.

Irony: Saying something but meaning something else.

Lexicalization: The use of semantic features of words for positively or negatively representing a special idea

Number Game: Using numbers and statistics to prove a claim

Polarization: Locating people at two ends of a continuum those who think like us and are good ones and the other end
} 
and those who are not like us so are the bad people

Presupposition: The information which is assumed to be known by the audience(s).

Vagueness: Not giving enough detailed information to the audience because the writer or the speaker is not willing to reveal the whole truth or their exact meaning.

Victimization: Telling bad stories about the OTHERS because they don't belong to OUR pole of the continuum.

One of the other famous figures in CDA is Van Leeuwen who explains the three ways in which social actors can be presented in discourse and outlined three interdisciplinary models; centralist, pluralist and integrationist (Van Leeuwen, 1996). He considers not just text but also acoustic and visual elements of discourse. (Van Leeuwen, 2004).

Wodak's research focuses on sociolinguistics and the development of theoretical approaches to CDA. She also focuses on gender, language in politics, prejudice, discrimination, racism and the most famous work of her is in the field of anti-Semitism. Wodak's approach is very ethnographic, and she is interested in analyzing the role of history and socialand political events influencing discourse, which lead to discourse, historical method which includes the analysis of information and interpretation of the many layers of a written or spoken text.(1995;2002). Wodak and Ludwig (1999) assert that in any discursive communication power and ideologies are manifested and if the analyst is not aware of the background Knowledge and norms and values, then extracting the right meaning of the text won't be actualized.

Finally the last but by no means the least scholar whose contributions will be mentioned in this study is Norman Fairclough. One of the main approaches in CDA is that of Fairclough whose theory has been central to CDA. Fairclough $(1989,1992,1993,1995 a, 1995 b$; Chuliaraki \& Fairclough, 1999) has always described the objective of his approach as raising awareness. He under the influence of some social economists and political theorists (Facault, Laclau and Mouffe) makes associations between linguistically discourse analysis with political and social ideas. (Fairclough, 1992). His main concern has been discourse and power and introduces three steps to CDA: Description (the study of the form), Interpretation (examining the relationship between text and interaction), Explanation (the relationship between interaction and social effects). In one of his recent papers (2005) he brings about a discursive phenomenon called recontextualization in which an element of discourse may be extracted from one text and inserted into another one purposefully for implying a different meaning.

The above mentioned scholars' approaches have been fallowed by many other researches who have expanded the study in this field. In this study the aim is the analysis of a social text using earlier mentioned Van Dijk's framework.

\section{Methodology}

The methodological imperative of this paper, as mentioned in the introduction, is to depict how an everyday mundane text can be as ideologically saturated as a text like presidential speeches.(Kress 1993). To fulfill this aim two letters were chosen; The rational behind selecting these two letters as the corpus of analysis was justified in two main reasons. The first was the originality of the work since most other research works were concerned with the CDA of people in power manipulating less powerful people while here the attempt was on the side of less powerfull people to have more powerful ones on their sides. The second and even more important reason was the fact that the texts were highly rich discursive strategies. The most appropriate analytical framework which seemed helpful to fulfill this aimwas Van Dijk's (2004) model. This model placed a great emphasis on two main strategies of positive self- presentation and negative other-presentation as the principal basis of discourse analysis because the discursive strategies of positive self presentation (i.e. semantic macro-strategy of in group favoritism) and negative other presentation (i.e. derogation of out group) were materialized through such discursive moves such as solidarity, hyperbole, disclaimer, number game, etc. So this analytical model was employed for the critical analysis of these letters under investigation.

\subsection{Data for the study}

There is a big famous language school with many different branches all around the country (Iran) and even different branches inside cities called (ILI). Each branch has a principal in charge of that branch and teachers may have one specific branch as their base but also teach in other branches. The staff of schools mainly includes teachers and the clerks who do the office work. The general manager of this school is at the central branch. This study is mainly the analysis of two complaint letters, one written by one of the teachers of this school complaining to the general manager about one of the principals' inappropriate reactions to her entering the teachers' room. And the other letter was written by the principal complaining about the same teacher and the same story. The reason why these letters were selected for this study was the fact that these two people tried to make different pictures of the same scene and convince the manager 
what they were expressing was right, however, one had applied more discursive techniques of representing a positive image of herself and negative image of the other person. In spite of the fact that this teacher herself admits that her entrance in the teachers' room of another branch without permission was not the right thing to do, she tries to enfeeble the evil of this act and instead exaggerate the principals bad reaction so that she will be able to convince the manager that what the principal had done was wrong and she needed to be reprimanded.

One of the other persuasive factors for the selection of these letters was its nature of being different from most works in CDA. As said before many studies have been conducted investigating how top rank authorities of countries use discourse to exercise power and dominance, however, this study aimed at showing how lower rank people can apply discursive strategies to express their views and ideology, and cause a change in their society even if as small as a school.

\subsection{Procedure}

The analytical framework utilized in this study is VanDijk's (2004) model to elaborate on how his strategies can be used in the text to materialize the fundamental dichotomies of "self positive- representation" and "others negative representation". He introduces these two major strategies in the form of an "ideological square"

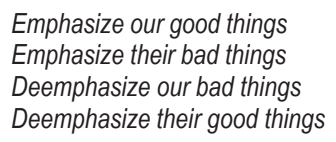

The teacher's full letter has been brought in the text and a few useful sample sentences of the principals' letter. For the sake of keeping confidentiality of the participants, names are changed. The strategic points are in bold. At the end the effect of this letter both at micro and macro level will be discussed.

\section{Teacher's Letter}

I am one of your school teachers who has devoted 11 years of her life teaching passionately.

This year, I have just registered my daughter in Hijab Branch. Since I am a Ph.D. student, to play my different roles of being a mother, wife, student, and teacher, time management is the most helpful factor for me.

This was the introduction to my story; the first session when my daughter was in class I spent one hour and thirty minutes in the hot yard next to the other ladies, and the time passed so inefficiently.

The second session I was frustrated looking for a way to make a better use of my time that I saw the sign of Teachers' room.

My respectful teacher, I am sure you know what "a teachers' room" means to a teacher. I know myself a member of this school family, so even in that branch I felt at home and for entering my room I didn't feel the need for permission. The door was open and hoping to find a friend I entered the room, but only chairs and a table, a good chance for me to study.

After about one hour, one of the teachers came in, after a short greeting left the room inquiringly and told the manager about my presence there.

The moment of my encounter with that lady was the beginning of the problem. The lady who seemed younger and less experienced than me, though none was a good reason for her to stand up or nod a head for greeting, treated me in a way as if I, a students studying, were a criminal committing a crime. Shame on me! Shame on ILI and shame on all the teachers in the world that neither my being a teacher nor my being an ILI member and not even being a client mattered to them.

My dear teacher, if this lady knew herself as a family member, wouldn't I be like a sister to her? But with a bitter frown and a tone even more bitter than her look, at the presence of other people, she told me that the teachers' room there belonged to the teachers of that branch only and I wasn't allowed to use it .( Even when all teachers were in class!!!) and that I wasn't allowed to go in.

Dear Sir, if this room is so secret how come my one hour being there was not even noticed.

My respectful manager, I very well remember the other day, on "Teachers' day", how you attempted to show me that I was important to you.

Yes sir! I admit I was mentally so occupied that I forgot to ask for permission but, the way I was reacted to didn't leave any room for apology.

I highly respect managers such as Ms. A, B, C, D, (names) for whom respecting the teachers and the clients is the priority, and you can ask them about me. I truly hope that this lady by learning the behavior of these qualified managers doesn't let the hard working attempts of this school teachers be in vain . 


\section{Analysis}

The writer of this letter very cunningly initiates her letter mentioning the number of years she has been working there to depict her loyalty and faith to that school. This way she has been able to express solidarity a sense of I have been with YOU. Then she continues by mentioning that this devoting has been passionately. There is a common concession that passion and love are essential attributes of a good teacher so by the use of lexicalization the writer is trying to present herself positively.

In the second part of the letter the writer describes herself as an important social actor, a Ph.D. student, for whom time management matters. Later in her sentence "I'm sure you know what a teachers' room means" she uses the presupposition element that since I know once you, like me, were a teacher, "you know how belonging to that room feels" she is asking for consensus.

In mentioning "the hot yard with other people" she doesn't think that she should have had the same condition as the others.

She uses the anaphoric mechanism by repeating the word "shame on" to invite the other teachers of that school (ILI) and the whole word to come to the consensus with her because according to her ideology disrespectful behavior to one teacher is equal to disrespecting the whole teachers in the world.

In the sentence "I know myself as a member of this family" the element of hyperbole is manifested in which that school has been assimilated to a home and the family she belongs to, as a result of which she can mitigate and deemphasize the wrong action of entering the room without permission, claiming that she felt as if she were entering her own room. While describing the principal lady she uses the terms "younger" or less "experienced" to create a negative attitude or imply that the lady was in an inferior position, here the official position of the principal (the good of others) is deemphasized. And again the hyperbole to exaggerate the bad behavior of treating her like a "criminal committing a crime".

Then the writer uses the conditional type two "If she knew herself ...." to imply that she doesn't know herself as a member she doesn't belong to US. By describing the embarrassing situation of being almost shouted at among the others the writer intends to evoke the manager's feeling of empathy. One of the most interesting strategies applied here is the way she addresses the manager; when talking about herself she addresses him as "my dear teacher" to create a feeling of empathy but when talking about the principal she calls him as "sir" to remind him of his role as a manager who should show a negative feedback to his employees' bad deed.

One could assume that the writer's mentioning of 70 minutes being in the room is a number game showing the irresponsibility of that principal's staff not noticing the presence of a strangers for so long the time. By talking about the "teachers' day" she wants to reemphasize the position of teachers in society where they are respect worthy and this respecting teachers is an accepted social norm. The use of a disclaimer is observed when she admits that her entering the room without permission was a mistake but not that big mistake to deserve that over reaction on the side of the manager.

Toward the end of the letter some other principals' names are stated. The names of authorities is used as a confirmation of her being good and that" this principal should learn how to treat teachers and..." is to imply that the principals who are aware of the high position of teachers and treat them appropriately are in the qualified pole of the continuum and the others on the other end (polarization).

On the other side of the story the principal lady did also try to justify her behavior, she had written a letter after introducing herself she had mentioned that "we noticed a stranger sitting in the teachers' room." Implying that if their reaction wasn't appropriate at the first place, their ignorance of the teachers' identity was the reason. So this shows that the principal's ideology is in accordance with the teacher's. In this lady's letter few mechanisms matching Van Dijk's framework were found. For justifying her reaction she had tried to depict a negative image of the teacher by mentioning that she had treated her arrogantly "she was too arrogant to show any respect for my position as a manager". According to this principal, teachers should be considered teachers just as long as they are in class teaching and when they have taken their children to school (even if the same school where they are working) they are the same as other parents, "I think teachers who take their children to other branches should be equal to other parents, and they shouldn't expect to receive any further services." "Teachers of a branch won't feel comfortable if someone from other branches is in their room." "Teachers should be informed about principal's high status and mustn't dare to be assertive facing them."

As it is clear the principal also is fighting for her high position. She does also try to have the manager's agreement and justify her behavior and establish a good position for herself and the other principals there. But it seems as if the rare use of discursive strategies trying to establish solidarity, lack of defining herself as an in group member, has made her text much less efficient than the teacher's. 


\section{Conclusion}

Whether power is in discourse, behind discourse, overt or subtle, it is not a permanent attribute; power is won, exercised, sustained and lost (Fairclough, 1990). Power holders are all the time trying to reassert their power, on the other hand powerless people try to gain it, and new trends show they have been successful in that.

This article has attempted to adopt CDA as a general theoretical framework to investigate if discursive characteristics can materialize the two macro strategies of "self- positive presentation" and "others negative presentation" introduced in Van Dijk's (2004) model in a written discourse as simple as letters of complaint to a manager.

In the analysis of two letters we could see the teacher was trying to resolve this problem both at this context level and also at a wider and higher level claiming respect and honor for the teachers in the whole society. To this end, she had applied discursive strategies to demonstrate a positive image of herself, techniques such as lexicalization and exaggeration and the use of some special structures had helped her achieve this aim. It was also explored how each writer had tried to embed those evil parts of her action and magnify the ones of the other one's.

The two main implications of this study, raising awareness and causing change, are the ultimate goals of CDA (Fair Clough).

The first inclination of this study is to make managers or people in power aware of the manipulative power of the words so that they will be cautious in contexts when making fair judgments are vital.

The second aim of CDA is causing change; and as it was detected the teacher's familiarity and use of discursive strategies caused a great change in the condition of that school.

Although there is no text available the investigations have revealed that the manager has commanded the principal to let the teacher use teachers' room as long as her daughter studies there and he had also announced that any teachers of the ILI should be welcome in other branches, they mustn't be treated as the others, they don't need to wait in registration lines, and more amazing was the fact that the manager had planned some in service training courses for the principals to teach them how to react facing similar cases.

Does CDA aim at doing anything more than a good change?

\section{References}

Bell, A. \& P., Garrett (1998). Approaches to Media Discourse. Blackwell, Oxford.

Biria, R. \& A. Mohammadi (2012). The socio pragmatic functions of inaugural speech: A critical discourse analysis approach. Sciverse Science Direct Journal of pragmaticsn 4(4), 1290-1302

Chouliaraki, L. \& N. Fairclough (1999). Discourse in late modernity: Rethinking Critical discourse analysis. Edinburgh: Edinburgh University Press.

Duranti, A. (2006). Narrating the Political Self. Language in Society 35, 467-497.

Emrich, Cynthia, Brower, Holly H., Feldman, Jack Michael, Howard, Garland (2001). Images in words: Presidential rhetoric, charisma, and greatness. Administrative Science Quarterly 46, 527-557.

Engel, D. (2004). Modeling self and other: A hybrid approach to the analysis of images of self and other in the radio addresses.

Fairclough, N. \& R. Wodak (1997). Critical discourse analysis. In T. A. Van Dijk (ed.), Discourse studies: A multidisciplinary introduction, (pp. 258-284). London: Sage Publications,

Fairclough, N. (1989). Language and power. London: Longman

Fairclough, N. (1992). Discourse and social change. Cambridge: Polity press

Fairclough, N. (1995). Critical discourse analysis: The critical study of language. New York: Longman.

Flowerdew, J. (2013) Discourse in English language education. London and New York: Routledge

Fowler, R. \& B. Hodge \& G. Kress \& T. Trew (1979). Language \& control. London: Routledge \& Kegan Paul.

Hodge, R. \& Kress, G. (1993). Language as Ideology. London: Routledge

Kratzer, J. \& W. Benoit (2010) A functional analysis of press release from Senator Barak Obama and Senator John McCain during the 2008 primary presidential election. Public Relations Review 36, 178-180

O'Halloran, K. (2005). Mystification and social agent absences: A critical discourse analysis using evolutionary psychology. Journal of pragmatics, 37, 1945-1964.

Piotr, C. (2014). Applying cognitive pragmatics to critical discourse studies: A proximization analysis of three public space discourses. Scientific journal of pragmatics, 7, 16-30

Rashidi, N. \& M. Souzandefar (2010). A critical discourse analysis of debates between republicans and democrats over the contribution of war in Iraq July 3.

Thompson, M. (2002b). ICT, Power, and Development Discourse: A Critical Analysis. Retrieved May 2009 from: http:// www. Jims.cam.ac.UK/esearch/Seminar/slides/2003/030529-thompson-9b.pdf.

Van Dijk, T. A. (1988). Critical discourse analysis. In Schiffrin, d. \& Tannen, D. The handbook of critical discourse analysis . Blackwell.

Van Dijk, T. A. (1991) Racism and the press. London: Routledge. 
Van Dijk, T. A. (1993). Principles of critical discourse analysis. Discourse \& society 4(2),249.283.

Van Dijk, T. A. (1995). Aims of critical discourse analysis. Japanese discourse 1(1), 17-27.

Van Dijk, T. A. (1996). Discours, Opinions and Ideologies. In Christina Schaffner \& Helen Kelly-Holmes (eds.) Discourse and Ideologies (PP. 37-77). Clevedon: Multilingual matters Ltd, 1996.

Van Dijk, T. A. (1997). Critical a discourse Analysis ' [on line], http: //www.hum.uva.n//teun/cda.htm(accessed $20^{\text {th }}$ February 2012

Van Dijk, T. A. (1997). Discourse as structure and process. London, available in: www.hum.Uva.nl

Van Dijk, T. A. (1998a). Critical discourse analysis .Available :http://www.hum.uva.nl/teun/cda.h

Van Dijk, T. A. (1998b). Opinions and ideologies in the press. In Bell. Allan and Peter Garrett (Eds.) Approaches to media discourse. Oxford: Blackwell

Van Leeuwen, T. (2004). Introducing social semiotics. London: Routledge.

VanDijk, T. A. (2004). Politics, Ideology and discourse. Retrieved February 20, 2008 from http://wwww.discourse-in-society.org/teun.html VanLeeuwen, T. J. (1996). The representation of social actors. In C.R.Caldas-Coulthard, \& M.Caulthard (Eds.), Texts and practices. Readings in Critical Discourse analysis. London: Routledge.

Wodak, R. (1999). The Discourse Construction of National Identity. Edinburgh University Press, Edinburgh.

Wodak, R. (2001). The discourse-historical approach. In R.Wodak, \& M.Meyer (Eds.) Methods of critical discourse analysis. London: Sage

Wodak, R. (2002). Aspects of critical discourse. ZFAL, 36, 5-31. 